\title{
Distribution of genotypes in the $5^{\prime}$ untranslated region of hepatitis $\mathrm{C}$ virus in Korea
}

\author{
Y. S. PARK*,+ K. O. LEE*, M. J. OH* and Y. G. CHAIt \\ * Department of Genetic Analysis, Seoul Clinical Laboratories (SCL), Seoul Medical Science Institute, Seoul \\ 140-230 and †Department of Biochemistry and Molecular Biology, Hanyang University, Ansan 425-791, Korea
}

\begin{abstract}
Hepatitis $\mathrm{C}$ virus (HCV) is an important human pathogen that can cause acute and chronic hepatitis, liver cirrhosis and hepatocellular carcinoma. Recently, partial and entire sequence data from $\mathrm{HCV}$ isolates have been reported, suggesting various genotypes of $\mathrm{HCV}$. The genotype may be correlated with the progression of hepatitis and maybe a prognostic marker of treatment. Thus, the availability of an assay for typing HCV RNA is important. This study developed a convenient method for genotyping HCV into six groups by PCR-RFLP with four restriction endonucleases (BstUI, HaeIII, NciI, RsaI) in the $5^{\prime}$ untranslated region (UTR) of HCV. The HCV genotypes from 169 patients with $\mathrm{HCV}$ infections in Korea were analysed. Two genotypes, type $1 \mathrm{~b}$ and type $2 \mathrm{a}$, accounted for $47.3 \%$ and $42.6 \%$ of $\mathrm{HCV}$ infections, respectively.
\end{abstract}

\section{Introduction}

The major aetiological agent of post-transfusion and community-acquired non-A, non-B hepatitis has been identified as hepatitis $\mathrm{C}$ virus ( $\mathrm{HCV})$, which is distantly related to the pestiviruses and flaviviruses [1-3]. A high rate of chronic hepatitis, including hepatocellular carcinoma, is associated with $\mathrm{HCV}$ infection [4]. HCV contains a positive strand RNA genome composed of $c$. 9500 nucleotides that can encode a large viral polyprotein of $c .3010$ amino acids $[5,6]$.

Comparative sequence analysis of $\mathrm{HCV}$ genomes has shown that $\mathrm{HCV}$ can be grouped into distinct but related genomes from the complete genomic sequence of fragments amplified by reverse transcription-polymerase chain reaction (RT-PCR) [7-9]. Genotypes with numerous subtypes have been described by the nomenclature proposed by Simmonds et al. [10-12]. They can be classified into six major groups or types provisionally designated $1-6$ and divided further into genotypes or subtypes $1 \mathrm{a}, 1 \mathrm{~b}, 2 \mathrm{a}, 2 \mathrm{~b}, 3 \mathrm{a}, 3 \mathrm{~b}$ and 4 , etc. HCV can be typed by RT-PCR and restriction fragment length polymorphism (RFLP) analysis of the $5^{\prime}$ untranslated region (UTR), which has a distinct nucleotide sequence $[11,13-15]$. HCV genotyping is potentially important in viral transmission studies,

Received 8 July 1997; revised version received 25 Nov. 1997; accepted 12 Dec. 1997.

Corresponding author: Dr Y. S. Park.
$\mathrm{HCV}$ epidemiology, and in predicting the success of interferon treatment [16-18].

This study investigated a method of HCV genotyping in the $5^{\prime}$ UTR with PCR-RFLP and analysed the genotypes of $169 \mathrm{HCV}$ isolates from patients with $\mathrm{HCV}$ infection in Korea.

\section{Materials and methods}

Serum samples

One hundred and sixty-nine blood samples were obtained from $\mathrm{HCV}$ patients who were found to be HCV positive by RT-PCR in Korea. To prevent contamination of HCV RNA for PCR, whole blood was collected in vacuum containers and was not separated into any other tubes.

\section{Extraction of HCV RNA and RT-PCR}

RNA was extracted from $100 \mu 1$ of serum by the guanidinium isothiocyanate and phenol-chloroform method with RNAzol B solution [19]. A combined RT-PCR was used to amplify HCV RNA. Five $\mu$ of RNA extract were added to a 500- $\mu 1$ PCR tube containing $1 \times$ PCR buffer $(50 \mathrm{mM} \mathrm{KCl}, 10 \mathrm{~mm}$ Tris$\mathrm{HCl}, \mathrm{pH}$ 9.0, Triton X-100 $0.1 \%, 1.5 \mathrm{mM} \mathrm{MgCl}_{2}$ ), $0.2 \mathrm{mM}$ of each dNTPs (dATP, dTTP, dGTP and $\mathrm{dCTP}), 1.0 \mathrm{U}$ of Thermoprime plus DNA polymerase (Advanced Biotechnologies), $5 \mathrm{U}$ of AMV reverse 
transcriptase, $20 \mathrm{U}$ of RNasin and 10 pmols of outer primers (sense; CTGTGAGGAACTACTGTCTT; antisense, ACTCGCAAGCACCCTATCAGG; size; 268 bp) from the 5' UTR. Reverse transcription was performed at $42^{\circ} \mathrm{C}$ for $45 \mathrm{~min}$ before denaturation at $95^{\circ} \mathrm{C}$ for 3 min. Thereafter, PCR was performed for 30 cycles of $1 \mathrm{~min}$ at $94^{\circ} \mathrm{C}, 1.5 \mathrm{~min}$ at $50^{\circ} \mathrm{C}$ and $1 \mathrm{~min}$ at $72^{\circ} \mathrm{C}$ in a 9600 thermal cycler (Perkin-Elmer). A final extension step of $72^{\circ} \mathrm{C}$ for $5 \mathrm{~min}$ was also included. Two $\mu \mathrm{l}$ of PCR product from the outer primer reaction were removed and transferred to a $250-\mu 1$ thin-wall tube containing fresh reagents and 20 pmols of inner primers (sense, TTCACGCAGAAAGCGTCTAG; antisense, TATCAGGCAGTACCACAAGG; size; 236 bp), and subjected to a further 25 cycles of $30 \mathrm{~s}$ at $94^{\circ} \mathrm{C}$, $45 \mathrm{~s}$ at $55^{\circ} \mathrm{C}$ and $45 \mathrm{~s}$ at $72^{\circ} \mathrm{C}$. The PCR products were separated by agarose $2 \%$ gel electrophoresis and visualised by staining with ethidium bromide.

\section{RFLP experiments and HCV genotyping}

HCV genotyping was performed by the RFLP method developed in this study. Restriction patterns of each
HCV genotype were analysed with the PC/GENE computer program (Intelligenetics), and four restriction endonucleases were selected (Bst UI, Hae III, Nci I and $R s a \mathrm{I})$. Samples $(5 \mu \mathrm{l})$ of the nested PCR product were digested with $5 \mathrm{U}$ of each restriction endonuclease (New England Biolabs) in the appropriate buffer for $4 \mathrm{~h}$ at each incubation temperature. The digested products were separated by electrophoresis on polyacrylamide $13 \%$ gel at $100 \mathrm{~V}$ for $3 \mathrm{~h}$. The DNA fragments were visualised by ethidium bromide staining and compared with the patterns of each $\mathrm{HCV}$ genotype analysed.

\section{Direct sequencing}

The HCV typing by PCR-RFLP was confirmed by direct sequencing. For direct autosequencing, the PCR products produced by inner primer were purified by a QIAquick PCR purification kit (Qiagen), and sequenced by the multi-colour fluorescent technique following the manufacturer's instructions in an ABI 310 genetic analyser (PE Applied Biosystems).

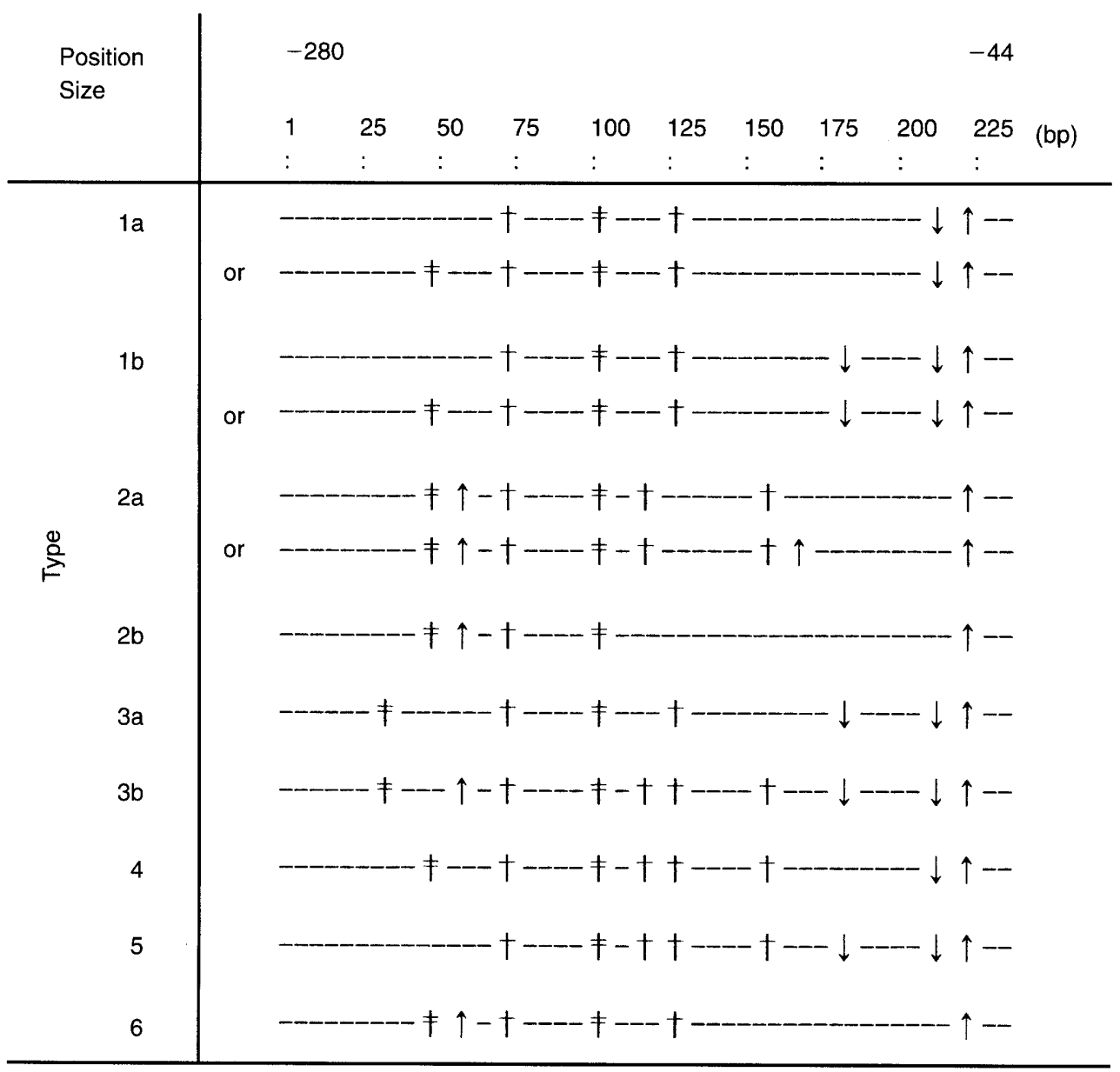

Fig. 1. Restriction map predicted from 5' UTR for HCV genotyping. The size from position -280 to -44 in the 5 ' UTR of HCV was $236 \mathrm{bp}$. Types $1 \mathrm{a}$ and $1 \mathrm{~b}$ have specific bands with Bst UI; and type 2a with HaeIII and NciI; type $2 \mathrm{~b}$ has no restriction site with BstUI; and type $3 \mathrm{a}$ has a specific band with HaeIII and RsaI, and type $3 \mathrm{~b}$ with NciI and

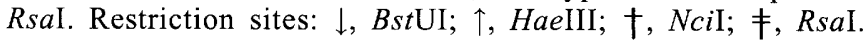




\section{Results}

RNA was extracted from serum samples of a wide range of $\mathrm{HCV}$-infected individuals and $\mathrm{HCV}$ genotyping was performed by the RFLP method combined with RT-PCR. The size of PCR product from the inner primers was $236 \mathrm{bp}$, and sequences of each type were

Table 1. Distribution of HCV genotypes from 5' UTR in 169 patients with HCV infection in Korea

\begin{tabular}{|c|c|}
\hline Genotype & Number $(\%)$ of cases \\
\hline $1 \mathrm{a}$ & $5 \quad(3.0)$ \\
\hline $1 b$ & $80(47.3)$ \\
\hline $2 a$ & $72(42.6)$ \\
\hline $2 b$ & $4 \quad(2.4)$ \\
\hline Mixed infection & $2^{*}(1.2)$ \\
\hline Untypable & $6 \quad(3.6)$ \\
\hline Total & 169 \\
\hline
\end{tabular}

${ }^{*} \mathrm{HCV}$ types of mixed infection were identified as type $1 \mathrm{a} / 1 \mathrm{~b}$ and $2 a / 2 b$, and were not classified separately. analysed by restriction endonucleases Bst UI, Hae III, $N c i$ I and RsaI. Fig. 1 shows the predicted restriction map at the 5' UTR of the six genotypes analysed in this study. The restriction sites of $5^{\prime}$ UTR sequences of each HCV type were compared and and analysed. HCV-1 (accession number; M62321), HCV-H (M67463), PT-1, H77, HC-J1 (D10749), GM1, GM2 and $\mathrm{H} 90$ belong to a group designated as type la. Type lb contains HCV-J (D90208), HCV-BK (M58335), HCV-JK1 (X61596), HCV-China (L02836), HCV-T (M84754), HCV-JT (D11168), HCV-J4/83 (D13558), HCV-J4/91 (D10750), HCV-L2, HCV-JT' (D11355), HCV-N (S6220) and HCV-C2 (D10934). Type 2a contains HC-J6 (D00944), K2A and E-B9, and type 2b contains HC-J8 (D01221) and K2B. NZL1 (D17763), HCV-K3a (D28917) and Eb-1 belong to type 3a, HCV-Tr (D26556) to type 3b, GB358 (L29608) to type 4, BE96 (L29585) to type 5, and QC26 (U33431) to type 6. Each type had a specific
(A)
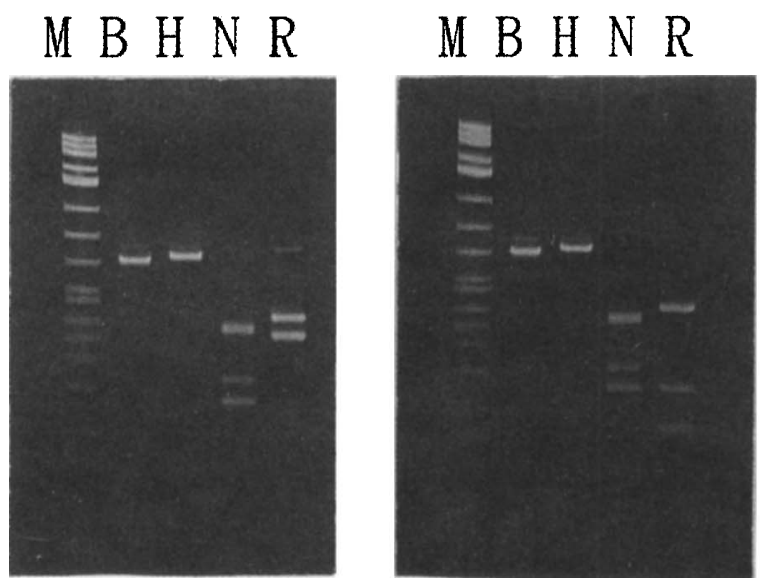

(C)
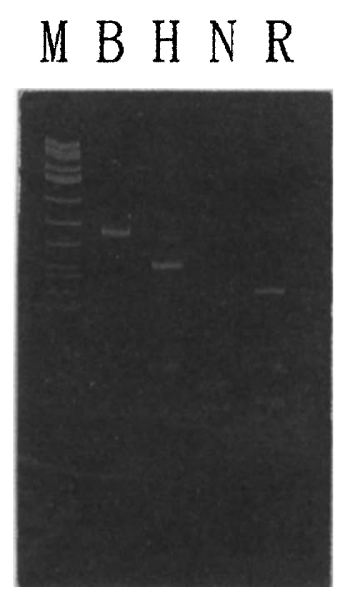
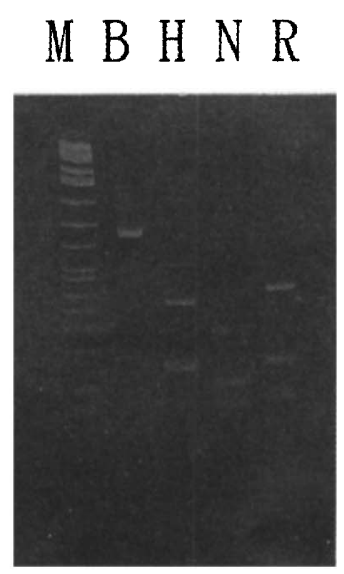

(B)
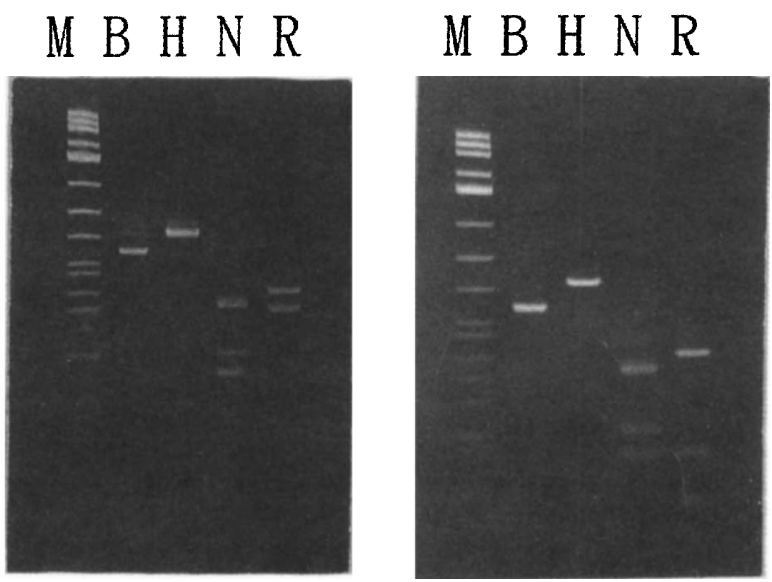

(D)

\section{B H N R}

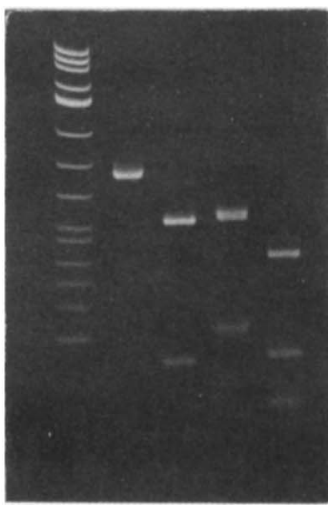

Fig. 2. HCV genotyping of types $1 \mathrm{a}, 1 \mathrm{~b}, 2 \mathrm{a}$ and $2 \mathrm{~b}$ by RFLP analysis. PCR products of 236 bp were digested with four restriction endonucleases and stained by ethidium bromide. Types $1 \mathrm{a}, 1 \mathrm{~b}$ and $2 \mathrm{a}$ have two restriction patterns in these results. Type 1a (A) has bands of specific sizes of 209 and $27 \mathrm{bp}$, and type $1 \mathrm{~b}$ (B) of 179, 30 and $27 \mathrm{bp}$ with Bst UI. Types $2 \mathrm{a}(\mathrm{C})$ and $2 \mathrm{~b}(\mathrm{D})$ have bands of $79,68,48$ and $41 \mathrm{bp}$, and 168 and $68 \mathrm{bp}$, respectively, with NciI. Types $1 \mathrm{~b}$ (B) and $2 \mathrm{a}(\mathbf{C})$ were found to be major types $(89.9 \%)$ in this study. M, Molecular standard marker of PhiX174/Hinfl; B, Bst UI; H, HaeIII; N, NciI; R, RsaI. 
Type 1b ctagccatggcgttagtatgagtgtTgtGcagcctccaggAcccccctcccgggagagccatagtggtctgcgg

Ncil

Type 2a ctagccatggcgttagtatgagtgtCgtAcagcctccaggCcccccctcccgggagagccatagtggtctgcgg

Rsal Haell Ncil

Type 1b aaccggtgagtacaccggaattgccAggaCgacCgggtcctttttggatCaacccGctcAatgccTggAGattt

Rsal Ncil

Type 2a aaccggtgagtacaccggaattgccGggaAgacTgggtcctttcttggatAaacccActcTatgccCggCCattt

Rsal Ncil Ncil Haell

Type tb gggcgtgcccccgcGagactgctagccgagtagTgttgggt $\underline{\text { gcgaaaggccttgt }}$

BstUl BstUl Haell

Type 2a gggcgtgccccgcAagactgctagccgagtagCgttgggTgcgaaaggccttgt

Haelll

Fig. 3. Nucleotide sequences of PCR products from two major types, type $1 \mathrm{~b}$ and $2 \mathrm{a}$, in Korea. Amplified products were purified and sequenced with an ABI 310 genetic analyser. The DNA sequences of two samples from each type were analysed and confirmed by reading the antisense strands.

band when secondary PCR products were digested with four restriction endonucleases, Bst UI, Hae III, Nci I and RsaI. Types $1 \mathrm{a}$ and $1 \mathrm{~b}$ produced two different restriction patterns with $R s a \mathrm{I}$, and type $2 \mathrm{a}$ had two patterns with HaeIII. The frequency of the six classified major genotypes from $169 \mathrm{HCV}$ RT-PCR positive patients in Korea was investigated. Type 1a was found in five cases $(3.0 \%)$, type $1 \mathrm{~b}$ in 80 cases $(47.3 \%)$, type $2 \mathrm{a}$ in 72 cases $(42.6 \%)$ and type $2 \mathrm{~b}$ in four cases $(2.4 \%)$, but types 3-6 were not found in this study (Table 1). There were mixed infections in two cases $(1.2 \%)$, which were identified as type $1 \mathrm{a} / 1 \mathrm{~b}$ and type $2 \mathrm{a} / 2 \mathrm{~b}$ co-infection. Six samples $(3.6 \%)$ had untypable restriction digestion patterns and their genotypes were indeterminate. The results show that HCV type $1 \mathrm{~b}$ or $2 \mathrm{a}(89.9 \%)$ were the major infections in Korea. Fig. 2 shows the results of the restriction patterns from each genotype produced by polyacrylamide $13 \%$ gel electrophoresis. The two main genotypes, $1 \mathrm{~b}$ and $2 \mathrm{a}$, were confirmed by direct sequencing (Fig. 3).

\section{Discussion}

$\mathrm{HCV}$ contain a positive polarity, single-stranded RNA genome with $5^{\prime}$ and $3^{\prime}$ UTR. The core (C), envelope 1 (E1) and envelope 2 (E2) proteins are encoded at the $5^{\prime}$ terminus and the non-structural proteins (NS) are encoded at the $3^{\prime}$ terminus of the single open-reading frame of the genome [20]. HCV is typical of RNA viruses in having a quasi-species nature due to relatively high mutation rates, particularly in the envelope regions of the genomes. The mutation rate is estimated to be $(1.44-1.92) \times 10^{-3}$ base substitu- tions/site/year [21]. The 5' UTR and NS4B region are most conserved, while the E1 and E2 regions show more variability [22-24]. Many of the assays that use type-specific primers can be predicted to either fail to differentiate genotypes or fail to amplify sequences unrecognised when the primers were originally designed. Analysis of the core region, which is generally less conserved than $5^{\prime}$ UTR, has been used previously for genotyping [12]. Because of the low mutation rate of the $5^{\prime}$ UTR $[13,14]$, patterns of nucleotide variability in the $5^{\prime}$ UTR were analysed. Furthermore, the $5^{\prime}$ UTR is the region of choice for detection and quantification of $\operatorname{HCV}[25,26]$, and can be conveniently used for genotyping by the RFLP method. One of the advantages of using the $5^{\prime}$ UTR for genotyping is the existence of a few identifiable polymorphisms between major genotypes that reliably associate with examples of the known genotypes. However, the method does not detect mixed infections easily. In a situation with mixed infection, either the predominant pattern alone prevails or an indeterminate pattern emerges, as the mixed digestion patterns appear together. In this study, two samples were detected as mixed infection of type $1 \mathrm{a} / 1 \mathrm{~b}$ and $2 \mathrm{a} / 2 \mathrm{~b}$, respectively; and six samples had restriction digestion patterns that were not typable into the predicted patterns. Nakao et al. and McOmish et al. have reported RFLP-based $\mathrm{HCV}$ genotyping methods [14, 27]. Nakao et al. detected only two HCV-K1 and HCV-K2 types from the NS5 region, compared with six different variable genotypes in the present assay. The method described by McOmish et al. was dependent upon the electrophoresis of radioisotope-labelled DNA fragments on acrylamide for a long period [27]. By contrast, the method used in the present study is less time- 
consuming and uses a simple non-isotope RFLP assay. Lee et al. reported that types $1 \mathrm{~b}(71 \%)$ and $2 \mathrm{a}(23.9 \%)$ were most common among $138 \mathrm{HCV}$ patients in Korea with type-specific primers [28]. However, this study showed that types $1 \mathrm{a}(47.3 \%)$ and $2 \mathrm{a}(42.6 \%)$ were major types. To confirm these findings, the two types were sequenced and confirmed as these genotypes. (Fig. 3).

HCV genotypes may be correlated with severity of liver disease. Genotype $1 \mathrm{~b}$ is associated with more severe hepatitis as well as a lower response to interferon than genotypes $2 \mathrm{a}$ and $2 \mathrm{~b}$ [29]. Patients with high serum levels of HCV RNA have a poor response to interferon, and patients infected with genotypes $1 \mathrm{~b}$ have higher levels of HCV RNA than those infected with other HCV genotypes [18]. Also, $\mathrm{HCV}$ genotypes have different geographic distributions; genotype $1 \mathrm{a}$ is prevalent in the UK and the USA and genotype $1 \mathrm{~b}$ is prevalent in Japan and Taiwan [30]. The distribution of HCV among Korean patients demonstrated mainly type $1 \mathrm{~b}$ and $2 \mathrm{a}$, as is the case in Taiwan.

In conclusion, genotyping based on $5^{\prime}$ UTR sequence analysis is possible and may complement studies on antiviral treatment and the transmission of $\mathrm{HCV}$, and may also have important implications for pathogenesis, diagnosis and vaccine development.

This work was supported by a grant from Seoul Medical Science Institute of Korea (SM97003).

\section{References}

1. Choo Q-L, Kuo G, Weiner AJ, Overby LR, Bradley DW, Houghton $M$. Isolation of a cDNA clone derived from a bloodborne non-A, non-B viral hepatitis genome. Science 1989; 244: $359-362$.

2. Kato N, Hijikata M, Ootsuyama Y et al. Molecular cloning of the human hepatitis $C$ virus genome from Japanese patients with non-A, non-B hepatitis. Proc Natl Acad Sci USA 1990; 87: $9524-9528$

3. Miller RH, Purcell RH. Hepatitis $\mathrm{C}$ virus shares amino acid sequence similarity with pestiviruses and flaviviruses as well as members of two plant virus supergroups. Proc Natl Acad Sci USA 1990; 87: 2057-2061.

4. Saito I, Miyamura M, Ohbayashi A et al. Hepatitis C virus infection is associated with the development of hepatocellular carcinoma. Proc Natl Acad Sci USA 1990; 87: 6547-6549.

5. Cho YG, Yoon JW, Jang KL, Kim CM, Sung YC. Full genome cloning and nucleotide sequence analysis of hepatitis $\mathrm{C}$ virus sera of chronic hepatitis patients in Korea. Mol Cells 1993; 3: 195-202.

6. Okamoto H, Okada S, Sugiyama Y et al. Nucleotide sequence of the genomic RNA of hepatitis $\mathrm{C}$ virus isolated from a human carrier: comparison with reported isolates for conserved and divergent regions. J Gen Virol 1991; 72: 2697-2704.

7. Bukh J, Purcell RH, Miller RH. Sequence analysis of the core gene of 14 hepatitis C virus genotypes. Proc Natl Acad Sci USA 1994; 91: 8239-8243.

8. Cha T-A, Beall E, Irvine B et al. At least five related, but distinct, hepatitis C viral genotypes exist. Proc Natl Acad Sci USA 1992; 89: 7144-7148.

9. Chan SW, McOmish F, Holmes EC et al. Analysis of new hepatitis $C$ virus type and its phylogenetic relationship to existing variants. $J$ Gen Virol 1992; 73: 1131-1141.
10. Simmonds P, Holmes EC, Cha TA et al. Classification of Hepatitis $C$ virus into six major genotypes and a series of subtypes by phylogenetic analysis of the NS-5 region. $J$ Gen Virol 1993; 74: 2391-2399.

11. Simmonds P, McOmish F, Yap PL et al. Sequence variability in the $5^{\prime}$ non-coding region of hepatitis $\mathrm{C}$ virus: identification of a new virus type and restricitons on sequence diversity. $J$ Gen Virol 1993; 74: 661-668.

12. Okamoto H, Sugiyama Y, Okada S et al. Typing hepatitis C virus by polymerase chain reaction with type-specific primers: application to clinical surveys and tracing infectious sources. $J$ Gen Virol 1992; 73: 673-679.

13. Kleter GEM, VanDorn L-J, Bronwer JT, Schlam SW, Heijtink RA, Quint WGV. Sequence analysis of the $5^{\prime}$ untranslated region in isolates of at least four genotypes of hepatitis $C$ virus in the Netherlands. $J$ Clin Microbiol 1994; 32: 306-310.

14. Nakao T, Enomoto N, Takada N, Takada A, Date T. Typing of hepatitis $\mathrm{C}$ virus genomes by restriction fragment length polymorphism. $J$ Gen Virol 1991; 72: 2105-2112.

15. Valliammai T, Thyagarajan SP, Zuckerman AJ, Harrison TJ Diversity of genotypes of hepatitis $\mathrm{C}$ virus in southern India. $J$ Gen Virol 1995; 76: 711-716.

16. Dusheiko G, Schmilovitz-Weiss H, Brown A et al. Hepatitis C virus genotypes: an investigation of type-specific differences in geographic origin and disease. Hepatology 1984; 19: 13-18.

17. Hino K, Sainokami S, Shimoda K et al. Genotypes and titers of hepatitis $\mathrm{C}$ virus for predicting response to interferon in patients with chronic hepatitis C. J Med Virol 1994; 42: 299-305.

18. Yoshioka K, Kakumu S, Wakita $\mathrm{T}$ et al. Detection of hepatitis $\mathrm{C}$ virus by polymerase chain reaction and response to interferon-alpha therapy: relationship to genotypes of hepatitis C virus. Hepatology 1992; 16: 293-299.

19. Chomczynski P, Sacchi N. Single-step method of RNA isolation by acid guanidinium thiocyanate-phenol-chloroform extraction. Anal Biochem 1987; 162: 156-159.

20. Takamizawa A, Mori C, Fuke I et al. Structure and organization of the hepatitis $\mathrm{C}$ virus genome isolated from human caries. J Virol 1991; 65: 1105-1113.

21. Okamoto H, Kojima M, Okada $S$ et al. Genetic drift of hepatitis $\mathrm{C}$ virus during an 8.2-year infection in a chimpanzee: variability and stability. Virology 1992; 190: 894-899.

22. Hada H, Koide N, Hanafusa $\mathrm{T}$ et al. Classification of hepatitis $\mathrm{C}$ virus into subgroups on the basis of sequence variations in the envelope protein. $J$ Gastroenterol Hepatol 1993; 8: S70-74.

23. Han JH, Shyamala V, Richman KH et al. Characterization of the terminal regions of hepatitis $C$ viral RNA: identification of conserved sequences in the $5^{\prime}$ untranslated region and poly $(\mathrm{A})$ tails at the $3^{\prime}$ end. Proc Natl Acad Sci USA 1991; 88: $1711-1715$.

24. Stuyver L, van Arnhem W, Wyseur A, Hernandez F, Delaporte E, Maertens G. Classification of hepatitis $C$ virus based on phylogenetic analysis of the envelope 1 and nonstructural $5 \mathrm{~B}$ regions and identification of five additional subtypes. Proc Natl Acad Sci USA 1994; 91: 10134-10138.

25. Karachristos A, Linardopoulos S, Ergazaki M, Spandidos DA. Detection and analysis of hepatitis $\mathrm{C}$ virus by a combined RTPCR method: variation in the $5^{\prime}$ non-coding region of the viral genome. J Med Microbiol 1995; 42: 367-371.

26. Park Y-S, Lee K-O, Oh M-J, Chai Y-G. Quantitation of hepatitis C viral RNA using direct CRT-PCR. J Biochem Mol Biol 1997; 30: 234-236.

27. McOmish F, Chan SW, Dow BC et al. Detection of three types of hepatitis $\mathrm{C}$ virus in blood donors: investigation of typespecific differences in serologic reactivity and rate of alanine aminotransferase abnormalities. Transfusion 1993; 33: 7-13.

28. Lee DS, Sung YC, Whang YS. Distribution of HCV genotypes among blood donors, patients with chronic liver disease, hepatocellular carcinoma, and patients on maintenance hemodialysis in Korea. J Med Virol 1996; 49: 55-560.

29. Takada N, Takase S, Enomoto N, Takada A, Date T. Clinical backgrounds of the patients having different types of hepatitis $\mathrm{C}$ virus genomes. J Hepatol 1992; 14: 35-40.

30. McOmish F, Yap PL, Dow BC et al. 1994. Geographical distribution of hepatitis $\mathrm{C}$ virus genotypes in blood donors: an international collaborative survey. J Clin Microbiol 1994; 32: 884-892. 